\title{
Neglected Basal Cell Carcinoma With Fatal Outcome
}

\author{
Jenna Pakka ${ }^{1}$, Joanna Holm², Annika M. Börjesson³, Christina B. Halldin ${ }^{1}$ John Paoli ${ }^{1}$
}

\begin{abstract}
1 Department of Dermatology and Venereology, Institute of Clinical Sciences, Sahlgrenska Academy, University of Gothenburg, Gothenburg, Sweden

2 Department of Dermatology and Venereology, Uddevalla Hospital, Uddevalla, Sweden

3 Department of Radiology, Sahlgrenska University Hospital, Gothenburg, Sweden
\end{abstract}

Key words: basal cell carcinoma, metastasis, patient delay, hedgehog inhibitor

Citation: Pakka J, Holm J, Börjesson AM, Halldin CB, Paoli J. Neglected basal cell carcinoma with fatal outcome. Dermatol Pract Concept. 2019;9(4):295-296. DOI: https://doi.org/10.5826/dpc.0904a09

Accepted: March 7, 2019; Published: October 31, 2019

Copyright: @2019 Pakka et al. This is an open-access article distributed under the terms of the Creative Commons Attribution License, which permits unrestricted use, distribution, and reproduction in any medium, provided the original author and source are credited.

Funding: None.

Competing interests: The authors have no conflicts of interest to disclose.

Authorship: All authors have contributed significantly to this publication.

Corresponding author: Jenna Pakka, MD, Department of Dermatology and Venereology, Institute of Clinical Sciences, Sahlgrenska Academy, University of Gothenburg, Gröna stråket 16, 41345 Gothenburg, Sweden. Email: jenna.pakka@vgregion.se

\section{Introduction}

Basal cell carcinoma (BCC) is the most common malignancy in Western populations. Metastatic BCC $(\mathrm{mBCC})$, however, is extremely rare and occurs in only $0.0028 \%-0.55 \%$ of cases. Despite the recent introduction of hedgehog pathway inhibitors, the prognosis for mBCC remains poor [1].

\section{Case Presentation}

A 73-year-old previously healthy Caucasian woman was admitted to Uddevalla Hospital because of her impaired general condition. Her hemoglobin level was $40 \mathrm{~g} / \mathrm{L}$ and she had experienced significant weight loss. Physical examination revealed a $37-\times 14-\mathrm{cm}$ ulcerated tumor from the cervical region vertebra $\mathrm{C} 7$ to the level of vertebrae L1-L2 (Figure 1A). The tumor had been growing on her back for the last decade. Biopsies of the tumor showed an infiltrative BCC. Three firm subcutaneous nodules could be visualized and palpated along the in-transit route toward the right axilla with 2 nodules located 1 and $7 \mathrm{~cm}$, respectively, from the ulcerated tumor and a third in the right axilla.

MRI showed infiltrative tumor growth into the underlying subcutaneous tissues including muscles and spinous processes. The presence of metastases was difficult to assess with computed tomography (CT) because of the large amount of pleural fluid (Figure 2A). Plastic surgeons were consulted, but the tumor was considered inoperable. Multidisciplinary consultation resulted in a recommendation of systemic therapy with the hedgehog pathway inhibitor vismodegib 150 mg per os per day.

During the first 3 months of treatment, the tumor shrank significantly to $24 \times 12 \mathrm{~cm}$. However, a new CT scan revealed a suspected metastasis $20 \mathrm{~mm}$ in diameter in the inferior lobe of the right lung and 4 smaller metastases in the inferior lobe of the left lung. Oncologists were consulted, but since the side effects of vismodegib were considered moderate (mild muscle cramps, diffuse alopecia, and ageusia), it was recommended that the patient continue with vismodegib.

After 7 months of treatment, a third CT scan detected several new 2- to $3-\mathrm{mm}$ metastases in both lungs, and the 
small metastases that were detected in previous CT scans had increased in size (Figure 2B). Furthermore, the healing process of the large BCC on the back had ceased (Figure 1B). The decreasing effect of vismodegib was suspected to be caused by resistance development. The treatment was finally discontinued after 12 months. The patient died 6 months later, which was 1 year and 10 months after the diagnosis.

\section{Conclusions}

This rare case is a reminder of the potential of BCCs to metastasize and even cause a fatal outcome. mBCC has been associated with a high mortality rate, with median survival of only 8-10 months after the diagnosis [2]. The tumor size was considered the only risk factor for $\mathrm{mBCC}$ in this patient. Because of the patient's unwillingness and the general palliative approach, biopsies were not taken to confirm that the lung metastases were from the BCC. However, the patient had no other known cancers or symptoms suggesting other origins. Although vismodegib showed good effect initially, the response was only partial. The response rate of this relatively new medicine in patients with mBCC has varied between $30.0 \%$ and $37.9 \%$ [1].

\section{References}

1. Kim JYS, Koslow JH, Mittal B, Moyer J, Olencki T, Rodgers P. Guidelines of care for
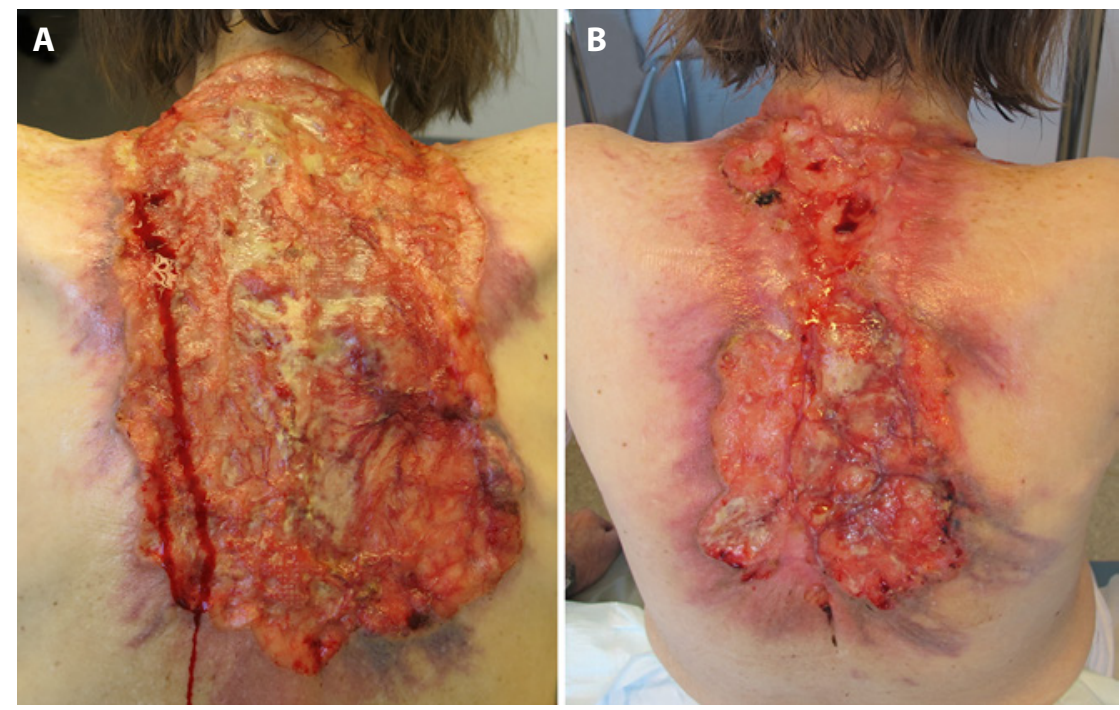

Figure 1. Clinical picture showing a massive tumor on the patient's back (A) before and (B) 6 months after the initiation of treatment with vismodegib. [Copyright: @2019 Pakka et al.]
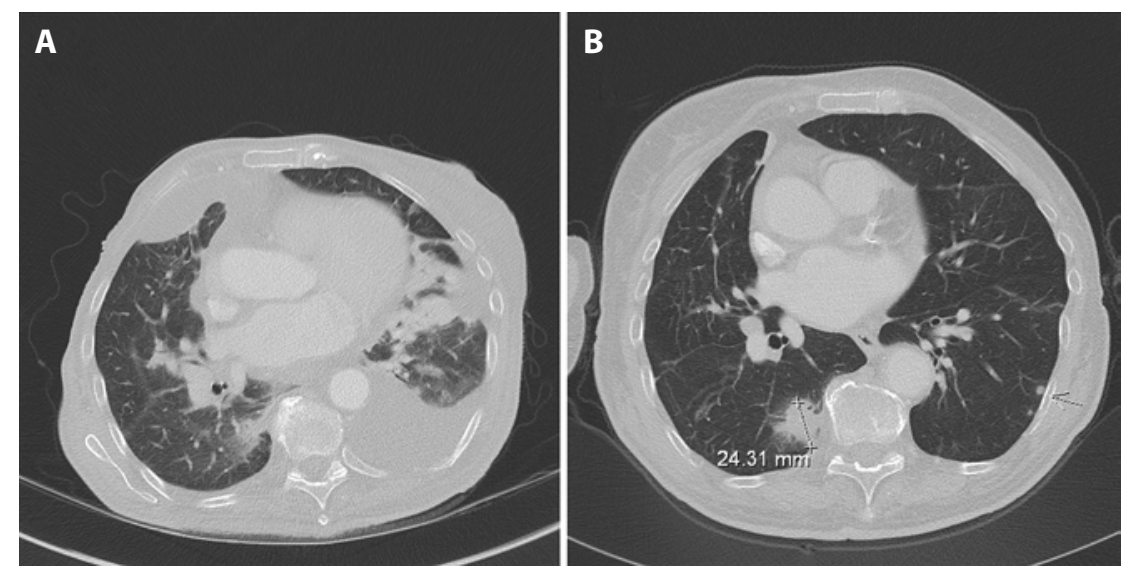

Figure 2. Computed tomography scan showing the progression of the metastases (A) before and (B) 6 months after the initiation of treatment with vismodegib. Initially, the lung metastases were difficult to assess because of the large amount of pleural fluid. [Copyright: (02019 Pakka et al.]

the management of basal cell carcinoma. $J$ Am Acad Dermatol. 2018;78(3):540-559.

2. Wysong A, Aasi SZ, Tang JY. Update on metastatic basal cell carcinoma: a summa- ry of published cases from 1981 through 2011. JAMA Dermatol. 2013;149(5):615616. 